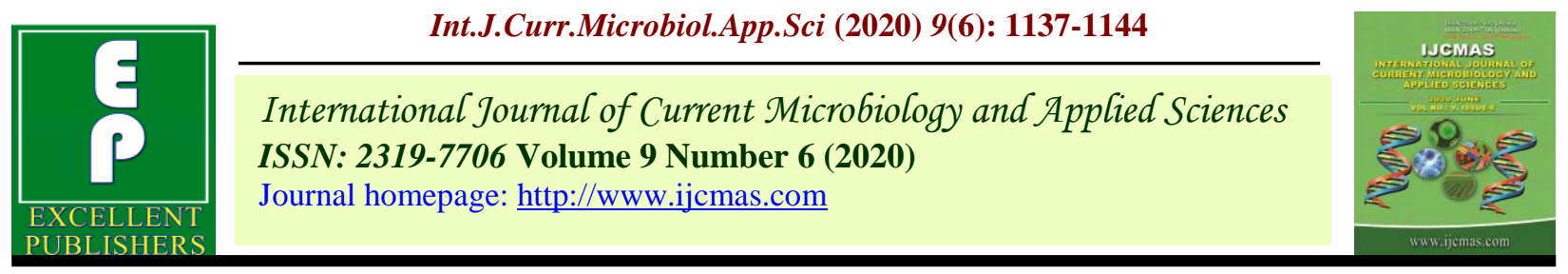

Original Research Article

https://doi.org/10.20546/ijcmas.2020.906.141

\title{
Response of Onion to NPK, S and Micronutrients
}

\author{
Joydip Mandal ${ }^{1 *}$, Pinaki Acharyya ${ }^{2}$, Rakesh Bera $^{2}$ and Smaranika Mohanta ${ }^{3}$ \\ ${ }^{1}$ Department of Horticulture and Post-Harvest Technology, Institute of Agriculture, \\ Visva-Bharati, Sriniketan - 731236 (West Bengal), India \\ ${ }^{2}$ Department of Horticulture, Institute of Agricultural Science, University of Calcutta, \\ Kolkata - 700019 (West Bengal), India \\ ${ }^{3}$ Department of Horticulture, M. S. Swaminathan School of Agriculture, Centurian University \\ of Technology and Management, Paralakhemundi (Odisha) - 761211, India \\ *Corresponding author
}

\section{A B S T R A C T}

Keywords

Allium cepa,

Nutrient, Sulphur,

Boron, Zinc, yield

Article Info

Accepted:

18 May 2020

Available Online:

10 June 2020

An experimental set up comprising of organic, primary, secondary and micronutrient combinations [FYM (15 t/ha), NPK (125:100:100 kg/ha), sulphur (40 $\mathrm{kg} / \mathrm{ha})$, boron $(0.2 \%)$ and zinc $(0.05 \%)$ ] were tried out to study the field response of onion cv. Sukhsagar under Red and lateritic zones of West Bengal, India. Results revealed that additional application of Sulfur, Boron and Zinc alone or in combinations with FYM and recommended dose of fertilizer increased the plant height, neck diameter and bulb diameters in onion. Maximum bulb weight and bulb was recorded with the application of FYM, NPK and sulphur with or without addition of boron and zinc. For quality parameters like dry weight, total and reducing sugar and TSS, no definite trend was noticed for nutrient application in onion. Overall interpretation of the gathered data suggests that soil application of FYM @ 15 t/ha and NPK @ 125:100:100 kg/ha along with sulphur $40 \mathrm{~kg} / \mathrm{ha} \& /$ or foliar application of B $(0.2 \%) \& / o r \mathrm{Zn}(0.05 \%)$ twice at 30 and 50 days after transplanting increases onion bulb yield.

\section{Introduction}

Onion (Allium cepa L.) is an important bulb vegetable of the plant family Alliaceae. Fresh, cooked as well as various processed form of onion are widely used for their unique flavor or for their flavor enhancement ability. In India, red or pink coloured, medium sized pungent onions are preferred, unlike white or yellow, mild flavored and sweet salad types of Japan, Europe and America. Onions can be stored for long period without much losses and it can withstand long distant transportation without upheaval. In 2016, India had $24.2 \%$ and $20.8 \%$ world onion area and production share respectively and ranked 
second after China. In India, the total production of onion during the year 2017-18 was estimated 232.62 lakhs MT from 12.85 lac hectare. In India, the major onion growing states are Maharashtra, Madhya Pradesh and Karnataka with production share of $38.1 \%$, $15.9 \%$ and $12.8 \%$ respectively. With 633.6 thousand MT productions from 35.2 thousand hectare, West Bengal ranked $8^{\text {th }}$ among the onion producing states of India, Nationally this was equivalent to $2.72 \%$ production from $2.74 \%$ land area of onion (Department of Agriculture, Cooperation \& Farmers' Welfare, 2018). Farmers of West Bengal mostly grow Rabi onion after harvesting of Kharif paddy. Harvesting of these onions is done during March - April months, of which part comes to the market and part is stored. States own production gets exhausted within three to four months and then the domestic demand is met by supply from Maharashtra and other Indian States. Thus, West Bengal depends on other Indian States for meeting up their internal onion demand for a major part of the year. Increase in production and productivity of Rabi onion, creation of improved stores for Rabi harvest and possibilities of growing Kharif and late Kharif onions are some of the viable options that can be explored to make the state near selfsufficient in onion (Dhar et al., 2016).

Crop management addresses various agronomical issues. Under suitable agroclimatic conditions, nutrient management is an important factor which influences the growth and yield of onion to great extent. Onions are more susceptible than most crop plants in extracting nutrients, because of their shallow and unbranched root system; hence they require and often respond well to additional fertilizers (Brewester, 1994). It is possible to produce higher yields of good quality bulbs by judicious application of nutrients. Other than major crop nutrients, sulphur is required in crops for pungency, oil contents and any other quality parameters. Onion and other Alliums are characterized by the presence of sulphur containing compounds, which give them their distinctive smell and pungency. According to Mondal et al., (2020) a considerable area of West Bengal is sulphur deficient or likely to become deficient except for the coastal and saline soils. As per SAI (Sulphur Availability Index), 87 per cent of the surface soil samples of Birbhum district fall under low sulphur range (Patra et al., 2012). Application of sulphur fertilizer proved beneficial for onion crop in this region (Meher et al., 2016 and Mondal et al., 2020). Boron is essential for plant growth and development. Adequate boron nutrition is critical for high yields and quality of crops. In vascular plants, boron moves from the roots with the transpiration stream and accumulates in growing points of leaves and stems (Blevins and Lukaszewski, 1998). Boron is known to be essential for cell wall structure and function, likely through its role as a stabilizer of the cell wall pectic network and subsequent regulation of cell wall pore size (Brown et al., 2008). According to Loomis and Durst (1992) up to $90 \%$ of the cellular boron has been localized in the cell wall fraction. Boron protects $\mathrm{Ca}$ in the cell wall by forming cross links in pectin. Boron requirement for reproductive growth in plants has long been recognized. It has been observed that in most plant species the boron requirement for reproductive growth is much higher than for vegetative growth. Boron effects on pollen germination, or on flowering and fruiting of plants (Blevins and Lukaszewski, 1998). World-wide, boron deficiency is extensive and it is particularly prevalent in light textured soils, where watersoluble boron readily leaches down the soil profile and becomes unavailable for plants. Total B (T-B) is quantified into five fractions: readily soluble (Rs-B), specifically adsorbed (Spa-B), oxide bound (Ox-B), organically bound (Org-B) and residual B (Res-B). 
Of these, Rs-B is the fraction present in soil solution and adsorbed weakly by soil particles, and is most readily available for plant uptake. It accounts for $1-2 \%$ of T-B (Padbhushan and Kumar, 2017). Zinc deficiency is an important malnutrition problem world-wide. Compared to adults, infants, children, adolescents, pregnant, and lactating women have increased requirements for zinc and thus, are at increased risk of zinc depletion (Roohani et al., 2013). Zinc is involved in many physiological functions and its inadequate supply will reduce crop yields. Zinc is required in various enzymatic reactions, metabolic processes, and oxidation reduction reactions in plants. In addition, $\mathrm{Zn}$ is also essential for many enzymes which are needed for nitrogen metabolism, energy transfer and protein synthesis (Hafeez et al., 2013). Zinc bio-fortification i.e. application of zinc fertilizers to soil and/or foliar seems to be a practical approach in improving grain zinc concentration. Agronomic biofortification can be achieved by increasing soil zinc phyto-availability or by applying zinc fertilizers. $\mathrm{ZnSO}_{4}$ is the widely applied source of zinc because of its high solubility and low cost (Roohani et al., 2013). Soil applied Zn had residual effects for subsequent crops but foliar sprays have no residual effect (Hafeez et al., 2013).

The onion productivity can be increased by selection of improved cultivar and good management practices. Better agro-techniques particularly nutrient management may improve the productivity and increase the production of onion. Locally adapted short day onion cultivar Sukhsagar occupies almost entire onion growing area of West Bengal. Haldar et al., (2009), Behera et al., (2017) and Mandal et al., (2019) worked on the identification of suitable onion types for West Bengal. Similarly, Mohanta and Mandal (2014), Mohanta et al., (2017) and Dhar et al., (2019) standardized the planting time in
Kharif onion in West Bengal. However, studies involving major plant nutrients, sulphur and micronutrients on onion were lacking particularly under Red and Lateritic Zone of West Bengal. Therefore, the present research work was aimed to study the field response of onion towards organic, primary, secondary and micro-nutrient combinations under Red and Lateritic Zone of West Bengal.

\section{Materials and Methods}

The experiment was conducted at Horticulture farm, Sriniketan (West Bengal), which is situated at $23^{\circ} 42^{\prime} \mathrm{N}$ latitude and $87^{\circ} 40^{\prime} 30^{\prime \prime} \mathrm{E}$ longitude with an average altitude of $40 \mathrm{~m}$ above mean sea level. The experimental site is situated in the sub-humid, sub-tropical, lateritic belt of West Bengal in the eastern part of India which experiences hot summer and moderately cold and short winter. Soil of the experimental site was loamy sand in texture with $\mathrm{pH} 5.6$ and organic carbon 0.56 $\%$. The available nitrogen, phosphorus and potassium content was found 205.7, 12.1 and $92.1 \mathrm{~kg} / \mathrm{ha}$. The seedlings were raised in permanent nursery beds for transplanting. On $30^{\text {th }}$ October 2018 , the onion seeds were sown in lines spaced at $5 \mathrm{~cm}$ distance after treating with Mancozeb 75\% WP (Indofil M 45; Indofil Industries Ltd., Mumbai) @ $2.5 \mathrm{~g} / \mathrm{kg}$ seed. Seedbeds were drenched with $0.2 \%$ Carbendazim 50\% WP solution (Bavistin; Crystal Crop Protection Ltd., Delhi) twice at 15 days and 25 days after sowing. The main field was ploughed, properly leveled and divided by irrigation channel into 24 plots of size $3 \mathrm{~m} \times 2 \mathrm{~m}$.

The crop was raised following Randomized Block Design with three replications. Onion cv. Sukhsagar was transplanted in the main field on $19^{\text {th }}$ December, 2018 following $15 \mathrm{~cm}$ $\mathrm{x} 10 \mathrm{~cm}$ spacing. The eight treatments, consisted of FYM (15 t/ha), NPK (125:100:100 kg/ha), sulphur (40 kg/ha), 
boron $(0.2 \%)$ and zinc $(0.05 \%)$ in various combinations were administered to the crop (Table 1). The $1 / 3^{\text {rd }}$ dose of nitrogen and potash and full dose of FYM (Farm Yard Manure), phosphorus and sulphur were applied to the field before transplanting. Rest doses of nitrogen and potash were applied 30 and 45 days after transplanting as top dressing. Nitrogen, phosphorus and potassium were applied in the form of Urea, Single Super Phosphate and Muriate of Potash respectively.

The source of sulphur was Sulfex Gold (Sulphur 80\% w/w; Excel Crop Care Ltd.). Boron and zinc were applied twice as spray at 30 and 50 days after transplanting. The source of boron was Di Sodium Octaborate Tetrahydrate (Boron 20 contains 20\% boron; Aries Agro Limited) and zinc was Chelated Zinc (Chelamin Plus contained Zn-EDTA 12\%; Aries Agro Limited) respectively. Two hand weedings were performed (25 and 50 Days after transplanting) to keep the crop free from weeds. Irrigations were given as and when required. Harvesting was done on $3^{\text {rd }}$ April 2018 when the leaves turned yellow and dry at the top with more than 50 per cent top fall visible. Harvested bulbs were field cured for two days followed by shed cured for seven days. Thereafter the dried leaves were removed by cutting from neck region, and the bulbs were stored in perforated plastic baskets.

Observations on plant height, number of leaves, neck diameter were taken from ten randomly selected competitive plants in each treatments and replication at 60 days after transplanting. The plant height was measured from ground level to the tip of the longest leaf. The number of fully grown, green and photosynthetically active leaves were recorded. The neck diameter below the joint of leaf lamina was measured with the help of digital vernier caliper. After harvesting, bulb polar and equatorial diameters and bulb weight was recorded from randomly selected ten bulbs and averaged. All the bulbs harvested plot wise were weighed after separating from the top. Yield per ha was computed from the yield obtained per plot. Five bulbs per treatments were taken randomly for laboratory analysis. Bulb dry matter was obtained by finely chopping the bulbs after removal of outer cover and drying in hot air oven until constant weight was achieved. The total soluble solid content was recorded with the help of Refractometer (Pocket Refractometer PAL 1, Atago, Tokyo; www.atago.net/) and was expressed in ${ }^{0}$ Brix. Sugar content of onion bulb was estimated following anthrone method as per Dubois et al., (1956). Both total and reducing sugars were estimated and expressed as percentage.

Laboratory studies were done in the Department of Horticulture, University of Calcutta, Kolkata. The data on all the parameters were subjected to statistical analysis. The total variation for different treatments was tested for significance by " $F$ " test using analysis of variance technique (Fisher and Yates, 1963). To compare the means of different cultivars, critical difference $(C D)$ was calculated.

\section{Results and Discussion}

Statistical analysis revealed that treatments were significantly differing among themselves for all the studied parameters. The results obtained have been presented in Table 2.

\section{Growth parameters}

Maximum plant height was observed in $\mathrm{FYM}+\mathrm{NPK}+\mathrm{S}+\mathrm{B}+\mathrm{Zn}$ which was noted statistically at par with $\mathrm{FYM}+\mathrm{NPK}+\mathrm{S}+\mathrm{Zn}$, $\mathrm{FYM}+\mathrm{NPK}+\mathrm{S}+\mathrm{B}, \quad \mathrm{FYM}+\mathrm{NPK}+\mathrm{Zn}, \quad \mathrm{FYM}+$ $\mathrm{NPK}+\mathrm{B}$ and $\mathrm{FYM}+\mathrm{NPK}+\mathrm{S}$. 
The results revealed that additional application of Sulfur, Boron and Zinc alone or in combinations with FYM and recommended dose of fertilizer increased the plant height in onion. Minimum plant height was observed in FYM. The number of leaves per plant was observed statistically similar for all treatments except FYM. Maximum neck diameter was observed when boron or zinc applied alone or in combination with sulphur in addition to FYM and NPK. On the other hand, minimum neck diameter was observed when onion was grown by FYM only.

\section{Yield and its attributing parameters}

Polar and equatorial diameter varied from 44.8 to $49.2 \mathrm{~mm}$ and 34.5 to $43.2 \mathrm{~mm}$. It was evident from the data that application of NPK with or without addition of sulphur \&/or micronutrients was helpful for getting more bulb diameters. On the other hand, only FYM application registered minimum bulb diameters. Bulb weight is an important yield attributing character. Average bulb weight significantly differed among the treatments. Average bulb weight ranged from 45.8 to 64.7 $\mathrm{g}$ with a mean of $57.9 \mathrm{~g}$. Maximum bulb weight was recorded with the application of FYM, NPK and sulphur with or without addition of boron and zinc. Minimum bulb weight was noted in only FYM application followed by FYM + NPK application. Onion bulbs yield differed significantly among the treatments. Similar to bulb weight maximum bulb yield was noted with the application of FYM, NPK and additional application of sulphur \&/or boron \&/or zinc. Minimum bulb yield was recorded in FYM closely followed by FYM + NPK. The results indicated the importance of sulphur, boron and zinc application in onion.

\section{Quality parameters}

Dry weight of onion did not differ much among the treatments. Baring $\mathrm{FYM}+\mathrm{NPK}+\mathrm{Zn}$, rest of the treatments were found statistically at par with each other. The TSS content ranged in between 11.6 and 14.0 ${ }^{\circ}$ Brix. Maximum TSS was observed in FYM+NPK, which was found at par with $\mathrm{FYM}, \mathrm{FYM}+\mathrm{NPK}+\mathrm{S}+\mathrm{B}$ and $\mathrm{FYM}+\mathrm{NPK}+\mathrm{S}$. No definite pattern was observed for nutrient application for TSS. Maximum total sugar content was observed in $\mathrm{FYM}+\mathrm{NPK}+\mathrm{S}$ followed by $\mathrm{FYM}+\mathrm{NPK}+\mathrm{S}+\mathrm{B}$, $\mathrm{FYM}+\mathrm{NPK}+\mathrm{B}$ and $\mathrm{FYM}+\mathrm{NPK}+\mathrm{Zn}$. However, application of $\mathrm{FYM}+\mathrm{NPK}+\mathrm{S}+\mathrm{B}$ and $\mathrm{FYM}+\mathrm{NPK}+\mathrm{S}+\mathrm{B}+\mathrm{Zn}$ gave minimum bulb reducing sugar content. All other treatments were noted statistically at par for this trait. For quality parameters no definite trend was noticed for nutrient application in onion.

Table.1 Treatment details of the experiment

\begin{tabular}{|c|c|c|}
\hline $\begin{array}{l}\text { SI } \\
\text { No. }\end{array}$ & Treatment code & Treatment details \\
\hline 1. & FYM & FYM @ 20 t/ha \\
\hline 2. & FYM+NPK & FYM + NPK @ 125:100:100 kg/ha \\
\hline 3. & $\mathrm{FYM}+\mathrm{NPK}+\mathrm{S}$ & FYM + NPK @ 125:100:100 kg/ha + S @40 kg/ha \\
\hline 4. & $\mathrm{FYM}+\mathrm{NPK}+\mathrm{B}$ & FYM + NPK @ 125:100:100 kg/ha + B @ 0.2\% \\
\hline 5. & $\mathrm{FYM}+\mathrm{NPK}+\mathrm{Zn}$ & FYM + NPK@ $125: 100: 100$ kg/ha + Zn @ 0.05\% \\
\hline 6. & $\mathrm{FYM}+\mathrm{NPK}+\mathrm{S}+\mathrm{B}$ & FYM+ NPK@125:100:100 kg/ha + S @40 kg/ha + B @0.2\% \\
\hline 7. & $\mathrm{FYM}+\mathrm{NPK}+\mathrm{S}+\mathrm{Zn}$ & FYM + NPK@125:100:100 kg/ha + S@ 40 kg/ha + Zn @ 0.05\% \\
\hline 8. & $\mathrm{FYM}+\mathrm{NPK}+\mathrm{S}+\mathrm{B}+\mathrm{Zn}$ & FYM + NPK @ 125:100:100 kg/ha + S @ 40 kg/ha + B @ 0.2\% + Zn @0.05\% \\
\hline
\end{tabular}


Table.2 Response of onion to nutrient treatments

\begin{tabular}{|c|c|c|c|c|c|c|c|c|c|c|c|}
\hline Treatments & $\begin{array}{c}\text { Plant } \\
\text { height } \\
\text { (cm) }\end{array}$ & $\begin{array}{c}\text { Number } \\
\text { of } \\
\text { leaves }\end{array}$ & $\begin{array}{c}\text { Neck } \\
\text { diameter } \\
(\mathrm{mm})\end{array}$ & $\begin{array}{c}\text { Polar } \\
\text { diameter } \\
(\mathbf{m m})\end{array}$ & $\begin{array}{c}\text { Equatorial } \\
\text { diameter } \\
(\mathrm{mm})\end{array}$ & $\begin{array}{c}\text { Average } \\
\text { bulb } \\
\text { weight (g) }\end{array}$ & $\begin{array}{l}\text { Bulb } \\
\text { yield } \\
\text { (t/ha) }\end{array}$ & $\begin{array}{c}\text { Dry } \\
\text { weight } \\
(\%)\end{array}$ & $\begin{array}{c}\text { TSS } \\
\left({ }^{\circ} \text { Brix }\right)\end{array}$ & $\begin{array}{l}\text { Reducing } \\
\text { sugar } \\
(\%)\end{array}$ & $\begin{array}{c}\text { Total } \\
\text { sugar } \\
(\%)\end{array}$ \\
\hline FYM & $51.1^{c}$ & $5.0^{\mathrm{b}}$ & $9.0^{\mathrm{d}}$ & $44.8^{b}$ & $34.5^{b}$ & $45.8^{\mathrm{d}}$ & $17.2^{c}$ & $13.3^{\mathrm{ab}}$ & $13.4^{\mathrm{ab}}$ & $1.3^{\mathrm{ab}}$ & $3.2^{\mathrm{bc}}$ \\
\hline FYM+NPK & $53.6^{\text {bc }}$ & $5.5^{\mathrm{a}}$ & $9.2^{\mathrm{cd}}$ & $45.9^{b}$ & $38.9^{\mathrm{ab}}$ & $55.5^{\mathrm{c}}$ & $17.9^{\mathrm{bc}}$ & $13.0^{\mathrm{ab}}$ & $14.0^{\mathrm{a}}$ & $1.4^{\mathrm{a}}$ & $3.2^{\mathrm{bc}}$ \\
\hline FYM+NPK+S & $57.0^{\mathrm{ab}}$ & $5.6^{\mathrm{a}}$ & $9.7^{\mathrm{bc}}$ & $46.5^{\mathrm{ab}}$ & $41.3^{\mathrm{a}}$ & $60.8^{\mathrm{ab}}$ & $21.8^{\mathrm{ab}}$ & $13.5^{\mathrm{ab}}$ & $12.7^{\mathrm{abc}}$ & $1.3^{\mathrm{ab}}$ & $3.6^{\mathrm{ab}}$ \\
\hline FYM+NPK+B & $57.2^{\mathrm{ab}}$ & $5.5^{\mathrm{a}}$ & $9.9^{\mathrm{ab}}$ & $47.0^{\mathrm{ab}}$ & $40.7^{\mathrm{a}}$ & $57.3^{b c}$ & $22.3^{\mathrm{a}}$ & $13.5^{\mathrm{ab}}$ & $12.4^{\mathrm{bc}}$ & $1.4^{\mathrm{a}}$ & $3.6^{\mathrm{ab}}$ \\
\hline FYM+NPK+Zn & $57.4^{\mathrm{ab}}$ & $5.6^{\mathrm{a}}$ & $10.2^{\mathrm{ab}}$ & $45.0^{b}$ & $42.5^{\mathrm{a}}$ & $57.9^{b c}$ & $20.5^{a b c}$ & $11.6^{b}$ & $11.7^{\mathrm{c}}$ & $1.2^{a b}$ & $3.4^{\mathrm{abc}}$ \\
\hline $\mathrm{FYM}+\mathrm{NPK}+\mathrm{S}+\mathrm{B}$ & $59.3^{\mathrm{a}}$ & $5.7^{\mathrm{a}}$ & $10.3^{a b}$ & $47.2^{\mathrm{ab}}$ & $40.7^{\mathrm{a}}$ & $56.8^{b c}$ & $19.8^{a b c}$ & $13.9^{\mathrm{a}}$ & $13.0^{a b c}$ & $1.1^{b}$ & $3.8^{\mathrm{a}}$ \\
\hline $\mathrm{FYM}+\mathrm{NPK}+\mathrm{S}+\mathrm{Zn}$ & $59.8^{\mathrm{a}}$ & $5.7^{\mathrm{a}}$ & $10.4^{\mathrm{a}}$ & $49.2^{\mathrm{a}}$ & $43.2^{\mathrm{a}}$ & $64.7^{\mathrm{a}}$ & $22.4^{\mathrm{a}}$ & $13.2^{\mathrm{ab}}$ & $11.7^{\mathrm{c}}$ & $1.2^{\mathrm{ab}}$ & $3.2^{\mathrm{bc}}$ \\
\hline $\mathrm{FYM}+\mathrm{NPK}+\mathrm{S}+\mathrm{B}+\mathrm{Zn}$ & $59.9^{a}$ & $5.6^{\mathrm{a}}$ & $10.5^{\mathrm{a}}$ & $49.2^{\mathrm{a}}$ & $42.5^{\mathrm{a}}$ & $64.2^{\mathrm{a}}$ & $21.6^{\mathrm{ab}}$ & $12.2^{\mathrm{ab}}$ & $11.6^{\mathrm{c}}$ & $1.1^{\mathrm{b}}$ & $3.0^{\mathrm{c}}$ \\
\hline Mean & 56.9 & 5.5 & 9.9 & 46.9 & 40.6 & 57.9 & 20.4 & 13.0 & 12.6 & 1.2 & 3.4 \\
\hline$C D(p=0.05)$ & 4.9 & 0.4 & 0.6 & 2.9 & 4.9 & 4.5 & 4.1 & 1.9 & 1.5 & 0.2 & 0.4 \\
\hline
\end{tabular}

NOTE: Means in a column bearing similar letters are statistically similar at $P \leq 0.05$ 
The study revealed that addition of NPK with FYM is only marginally beneficial than sole application of FYM. It appears that inclusion of $\mathrm{S}, \mathrm{B}$ and $\mathrm{Zn}$ alone or in combination helps to get relatively vigorous plant and additional yield. Onion productivity was influenced by $\mathrm{S}$ dose. In Brazil, De Souza et al., (2015) obtained $79 \mathrm{t} / \mathrm{ha}$ bulb yield at $45 \mathrm{~kg} \mathrm{~S} / \mathrm{ha}$.

However, they noted that onion productivity was $16 \%$ lower, when $S$ was not applied. In Red and Lateritic Zone of West Bengal, Meher et al., (2016) and Mondal et al., (2020) obtained more yield in onion by incorporating sulphur in addition to FYM and NPK. Mandal et al., (2013) found that application of organic inputs in combination with chemical fertilizer were better option than application of organic manure or chemical fertilizer alone in onion. Sharma et al., (2017) suggested to apply 20 t/ha FYM and NPK @ 125-100-100 kg /ha for getting higher productivity, net return and benefit-cost ratio in onion cv. Agrifound Dark Red.

The response of boron and zinc application was not much clear in this experiment. However, Manna and Maity (2016) reported that the foliar application of boron and zinc @ $0.5 \%$ significantly enhanced the growth, yield and quality of onion in the New Alluvial Zone of West Bengal. While Sethupathi (2019) observed that application of Soil Test Crop Response (STCR) (106:97:54 kg of NPK /ha) $+\mathrm{ZnSO}_{4} @ 25 \mathrm{~kg} /$ ha with $0.5 \%$ foliar spray gave better yield parameters, bulb qualities and higher net income.

From the present study, it can be concluded that soil application of FYM @ 15 t/ha and NPK @ 125:100:100 kg/ha along with sulphur $40 \mathrm{~kg} / \mathrm{ha} \& /$ or foliar application of B $(0.2 \%)$ \&/or Zn $(0.05 \%)$ twice at 30 and 50 days after transplanting can be done to obtain higher yield benefit in onion under Red and Lateritic Zone of West Bengal.

\section{References}

Behera, T. K., J. Mandal, S. Mohanta, A. K. Padhiary, S. Behera, D. Behera and Rout, R. K. 2017. Assessment of growth, yield and quality of onion genotypes under red and lateritic zone of West Bengal. Journal of Pharmacognosy and Phytochemistry. 6(6): 493-97.

Blevins, D. G., and Lukaszewski, K. M. 1998. Boron in plant structure and function. Annual Review of Plant Physiology and Plant Molecular Biology. 49: 481-500.

Brewster, J. L., 1994. Onions and other vegetable Alliums. CAB International, U.K. 236 p.

Brown, P. H., N. Bellaloui, M. A. Wimmer, E. S. Bassil, J. Ruiz, H. Hu, H. Pfeffer, F. Dannel and Römheld, V. 2008. Boron in Plant Biology. Plant Biology. 4(2): 205-223.

De Souza, L.F.G., A.B.C. Filho, F.A. De Túlio and Nowaki, R. H. D. 2015. Effect of sulphur dose on the productivity and quality of onions. Australian Journal of Crop Science. 9(8): 728-733.

Department of Agriculture, Cooperation \& Farmers' Welfare, 2018. Horticultural statistics at a glance. 2018. Horticulture Statistics Division, Department of Agriculture, Cooperation and Farmers' Welfare, Ministry of Agriculture and Farmers' Welfare, Government of India. 458 P. (www.agricoop.nic.in)

Dhar, M., J. Mandal and Mohanta, S. 2016. Prospects of onion cultivation (Allium cepa L.) in West Bengal. In: Rural Health, Women Empowerment and Agriculture: Issues and Challenges (Eds.) P. K. Chattopadhyay and D. S. Kushwaha. New Delhi Publishers, New Delhi. pp. 257-275.

Dhar, M., J. Mandal, T. K. Maity and Mohanta, S. 2019. Evaluation of kharif onion (Allium сера L.) varieties under different planting dates. Journal of Pharmacognosy and Phytochemistry. 8(2): 1317-21.

Dubois, M., K. A. Gilles, J. K. Hamilton, P. A. Rebers and Smith, F. 1956. Colorimetric Method for Determination of Sugars and Related Substances. Analytical Chemistry. 28 (3): 350-356.

Fisher, R.A., and Yates, F. 1963. Statistical Tables 
for Biological, Agricultural and Medical Research. Hafner Press, A Division of Macmillan Publishing Co., Inc. New York, pp. 1-155.

Hafeez, B., Y. M. Khanif and Saleem, M. 2013. Role of Zinc in Plant Nutrition- A Review. American Journal of Experimental Agriculture. 3(2): 374-391.

Haldar, A., C. Karak, A. Naik, M. K. Samanta and Hazra, P. 2009. Identification of suitable early rabi onion varieties under West Bengal condition. Journal of Crop and Weed. 5(1):124-129.

Loomis, W.D., and Durst, R.W. 1992. Chemistry and biology of boron. BioFactors. 3: 229239.

Mandal, J., C. Ghosh, and Chattopadhyay, G. N. 2013. Proportional Substitution of Chemical Fertilizers with Vermicompost on Growth and Production Potential of Onion (Allium cepa L.). International Journal of Bio-resource and Stress Management. 4(2): 356-357.

Mandal, J., R. Ajgalley, D. Saha and Mohanta, S. 2019. Growth, yield and quality of some onion (Allium cepa L.) cultivars under Lateritic Belt of Eastern India. Veg. Sci. 46(1\&2): 129-131.

Manna, D., and Maity, T.K. 2016. Growth, yield and bulb quality of onion (Allium cepa L.) in response to foliar application of boron and zinc, Journal of Plant Nutrition. 39(3): 438-441.

Meher, R., J. Mandal, D. Saha and Mohanta, S. 2016. Effect of sulphur application in onion (Allium cepa L.). Journal of Crop and Weed. 12(3):86-90.

Mohanta, S., and Mandal, J. 2014. Growth and yield of kharif onion (Allium cepa L.) as influenced by dates of planting and cultivars in Red and Laterite Zone of West
Bengal. Hort Flora Research Spectrum. 3(4): 334-338.

Mohanta, S., J. Mandal and Dhakre, D. S. 2017. Growth of kharif onion (Allium cepa L.) in response to planting dates and cultivars. Hort Flora Research Spectrum. 6(4): 262-267.

Mondal, S., G. K. Ghosh and Mandal, J. 2020. Effect of Graded Levels of Sulphur as Magnesium Sulphate on Yield and Quality of Onion (Allium cepa L.) in Red and Lateritic Soils of West Bengal, India. International Journal of Current Microbiology and Applied Sciences. 9(4): 1-9.

Padbhushan, R., and Kumar, D. 2017. Fractions of soil boron: a review. The Journal of Agricultural Science. 155(7): 1023-1032.

Patra, P., S. Mondal and Ghosh, G. K. 2012. Status of available sulphur in surface and sub-surface soils of red and Lateritic soils of West Bengal. International Journal of Plant, Animal and Environmental Sciences. 2: 276-281.

Roohani, N., R. Hurrell, R. Kelishadi and Schulin, R. 2013. Zinc and its importance for human health: An integrative review. Journal of Research in Medical Sciences. 18(2): 144157.

Sethupathi, S., 2019. Effect of Zinc and Boron on Yield and Quality of Onion (Allium cepa L.) in Alfisols of Tamirabarni Tract. International Journal of Agriculture Sciences. 11(1): 7725-7727.

Sharma, A., P. Panja and Mandal, J. 2017. Effect of intregated nutrient management on onion (Allium cepa L.) yield, quality attributes, soil properties and production economics under field condition. Indian Journal of Ecology. 44(Special Issue-5): 355-359.

\section{How to cite this article:}

Joydip Mandal, Pinaki Acharyya, Rakesh Bera and Smaranika Mohanta. 2020. Response of Onion to NPK, S and Micronutrients. Int.J.Curr.Microbiol.App.Sci. 9(06): 1137-1144. doi: https://doi.org/10.20546/ijcmas.2020.906.141 